\title{
Circadian Variations of Blood Sugar and Plasma Insulin Levels in IMan*
}

\author{
C. Malherbe**, M. DE Gasparo, R. DE Hertogh*** and J.J. Hoet
}

Laboratoire de Recherches de la Clinique Médicale, Hôpital Saint-Pierre, Université de Louvain, Belgique Received: March 15, 1969

Summary. Blood sugar, plasma insulin, non-esterified fatty acids (NEFA), plasma cortisol, and urinary catecholamines were measured for $24 \mathrm{~h}$ in seven normal subjects receiving a standard diet. During the night, blood sugar and plasma insulin remained low, NEFA decreased progressively, and the excretion of catecholamines diminished. During the day, the insulin response appeared particularly important after the morning meal. This last observation was also made when normal subjects were given three identical meals at intervals of four and a half hours. Under these conditions, the postprandial elevations of blood sugar were not statistically different, but the plasma insulin rose significantly higher after the morning meal. These observations may be explained by the exis. tence of a periodicity which would regulate the insulin secretion. It is also possible that the insulin liberated postprandially conserves a certain activity at the moment of the next meal, and still intervenes in the maintaining of blood sugar homeostasis. Later in the day, however, blood sugar homeostasis would necessitate a new synthesis of insulin, which would explain the delayed plasma insulin response to the evening meal.

Variations circadiennes de la glycémie et des taux plasmatiques d'insuline chez l'homme

Résumé. La glycémie, l'insulinémie, les acides gras non estérifiés, le cortisol plasmatique ainsi que les catécholamines urinaires ont été mesurés pendant $24 \mathrm{~h}$ chez sept sujets normaux recevant une alimentation standardisée. Durant la nuit, la glycémie et l'insulinémie restent basses, les taux plasmatiques d'acides gras non estérifiés diminuent progressivement et les catécholamines sont excrétées en moins grande quantité. Pendant le jour, la libération d'insuline paraît particulièrement importante après le repas du matin. Cette dernière constatation se vérifie aussi lorsqu'on administre à des sujets normaux trois repas identiques distants de quatre heures et demie. Dans ces conditions, en effet, les augmentations postprandiales de la glycémio ne sont pas statistiquement différentes, mais l'accroissement de l'insulinémie est significativement plus important après le repas du matin. Ces observations peuvent s'expliquer par l'existence d'une périodicité qui régirait l'insulino-sécrétion. Il est aussi possible que l'insuline libérée après un repas conserve une certaine activité et intervienne encore dans le maintien de l'homéostasie glycémique au moment du repas suivant. Le soir, l'augmentation prolongée de l'insulinémie suggère l'existence d'une nouvelle synthèse d'insuline.

Schwankungen des Blutzuckers und des Plasmainsulins beim Menschen im Tagesrhythmus.

Zusammenfassung. Bei sieben normalen und zwei übergewichtigen Personen, die standardisierte Mahlzeiten einnahmen, wurden während der Zeitspanne von $24 \mathrm{~h}$ Blutzucker, Plasma-Insulin, freie Fettsäuren, PlasmaCortisol sowie die Katecholamine im Urin bestimmt. Nachts bleiben Blutzuckerspiegel sowie Insulinkonzentration relativ niedrig, nehmen die freien Fettsäuren pro. gressiv ab und verringert sich ebenfalls die KatecholaminAusscheidung. Tagsüber ist die Insulinfreisetzung nach der Morgenmahlzeit stärker als mittags und abends. Dies trifft gleichfalls zu, wenn normalen Personen dreimal die gleiche Mahlzeit nach jeweils $4 \frac{1}{2} \mathrm{~h}$ verabreicht wird. Unter diesen Bedingungen ergibt sich, daß die Steigerung des Blutzuckerspiegels nach den jeweiligen Mahlzeiten nicht statistisch verschieden ist, jedoch der Insulinspiegel nach der Morgenmahlzeit signifikant höher liegt. Diese Beobachtungen können durch die Existenz einer Periodizität der Insulinsekretion zu erklären sein. Es ist ebenfalls möglich, daß das nach einer Mahlzeit sezernierte Insulin eine gewisse Dauer-Aktivität behält und somit noch auf die Homöostase des Blutzuckerspiegels während der nächsten Mahlzeit Einfluß nehmen kann. Nach der Abendmahlzeit läßt die länger andauernde Steigerung des Insulingehaltes auf das Bestehen einer erneuten gleichzeitigen Insulinsynthese schließen.

Key-words: Plasma insulin, blood sugar, non-esterified fatty acids, urinary catecholamines, circadian variations, meals.
The plasma levels of several hormones having an effect upon carbohydrate metabolism undergo cyclic variations over a 24 -h period. Such modifications have been reported for cortisol [13] and catecholamines [3], but have not been found for growth hormone $[18,23]$.

A circadian rhythm has been observed for blood sugar in the fasting rat $[17,15]$, although this finding has not been noted in the sheep [24], nor in the normal

* Presented at the Fourth Annual Meeting of the European Association for the Study of Diabetes, Louvain, July $23,1968$. fique.

** Aspirant du Fonds National de la Recherche Sienti-

*** Chargé de recherches du Fonds National de la Recherche Scientique. human [8]. However, such a rhythm seems to exist in the diabetic [8].

Faiman and Moorhouse [8] have not found any variation of plasma insulin in normal subjects, nor in diabetics during a three-day fasting period. Likewise, plasma insulin does not vary during sleep in the normal subject [23]. However, elevated plasma insulin levels have been observed at $24 \mathrm{~h}$ and $4 \mathrm{~h}$ in several patients suffering from various endocrinopathies and in three control subjects receiving a free diet during the day [12].

In this present work, 24-h variations of blood sugar and plasma insulin levels have been studied systematically in a homogeneous group of normal subjects receiving a standard diet made up of three different meals in the day. In another group of normal subjects, 
modifications of these two parameters produced by the ingestion of three identical meals at intervals of four and a half hours were studied and analyzed statisticalIy.

\section{Methods}

\section{Subjects and experimental conditions}

All subjects were normal and were given a diet comprising at least $200 \mathrm{~g}$ of carbohydrate per day, for three days prior to testing.

I. A first group received three standard meals of a different composition, corresponding to their average dietary habits (Table $1 \mathrm{~A}$ ) at $6.30 \mathrm{~h}, 11.30 \mathrm{~h}$ and $17 \mathrm{~h}$.

Table 1. Caloric content and composition of the different (A) and identical (B) meals

\begin{tabular}{lrlll}
\hline Meals & $\begin{array}{l}\text { Caloric } \\
\text { content }\end{array}$ & $\begin{array}{l}\text { Carbo- } \\
\text { hydrates } \\
(\mathrm{g})\end{array}$ & $\begin{array}{l}\text { Lipids } \\
(\mathrm{g})\end{array}$ & $\begin{array}{l}\text { Proteins } \\
(\mathrm{g})\end{array}$ \\
\hline A. Morning & 700 & 110 & 20 & 20 \\
Midday & $\mathbf{1 1 8 0}$ & $\mathbf{1 1 0}$ & 60 & 50 \\
Evening & 450 & 80 & 10 & 10 \\
\hline Total & 2330 & 300 & $\mathbf{9 0}$ & 80 \\
\hline B. Morning & & & & \\
Midday & 745 & $\mathbf{1 0 0}$ & $\mathbf{2 5}$ & 30 \\
Evening & 745 & 100 & $\mathbf{2 5}$ & 30 \\
\hline Total & $\mathbf{7 4 3 5}$ & $\mathbf{1 0 0}$ & $\mathbf{2 5}$ & $\mathbf{3 0 0}$ \\
\hline
\end{tabular}

It included seven male subjects; their average age, height and weight were respectively: $29.3 \pm 2.5$ years, $169 \pm 2.4 \mathrm{~cm}$ and $68.4 \pm 1.0 \mathrm{~kg}$ (mean $\pm \sigma$ ). During the night of the test, they remained in a supine position and were allowed to sleep. The following day, their activity was limited and smoking was prohibited.

Hourly, for $24 \mathrm{~h}, 5 \mathrm{ml}$ of venous blood was obtained by venipuncture from each subject. These blood samples were taken exactly on the hour for subjects FRA. ., MAT.., BRI.. and DUN.. (group a), and every hour on the half hour for subjects TOU.., DUC. . and VAN.. (group b).

Blood sugar, plasma insulin and non-esterified fatty acids (NEFA) levels were measured. Plasma cortisol was measured at the following times: $4 \mathrm{~h}, 9 \mathrm{~h}, 12 \mathrm{~h}$, $17 \mathrm{~h}, 20 \mathrm{~h}$ and $24 \mathrm{~h}$.

Urine specimens were collected from all subjects in a beaker containing $6 \%$ sulphuric acid, in two fractions of twelve hours each (from $20 \mathrm{~h}$ to $8 \mathrm{~h}$ and from $8 \mathrm{~h}$ to $20 \mathrm{~h}$ ). Urinary levels of adrenaline, noradrenaline, and vanilmandelic acid were measured.

II. Another group received three identical meals (Table $1 \mathrm{~B}$ ) at equal intervals (at $7.30 \mathrm{~h}, 12 \mathrm{~h}$ and 16.30 h). It included five male subjects; their average age, height and weight were respectively: $23 \pm 1.2$ years, $176 \pm 4.2 \mathrm{~cm}$ and $68 \pm 4.2 \mathrm{~kg}$. They rested also during the day of the test. An ordinary needle was placed in an antecubital vein of each subject, and a slow saline infusion was maintained throughout the test, assuring permeability of the needle. Five $\mathrm{ml}$ of venous blood were taken, beginning with a fasting sample, then at
$20,30,45,60,75,90,105,120,150,180,210,240$ and 270 min after each meal.

The blood sugar and plasma insulin levels were measured for each of these specimens.

\section{Assays}

The blood sugar was measured with the Technicon Auto-analyser, according to the method of Hoffman [10]; plasma insulin was determined by the double antibody method described by Morgan and Lazarow [14]; NEFA were evaluated by the method of Dole and Meinertz [5]; plasma cortisol was measured according to the method of Porter and Silber, following Peterson [16]. Urinary catecholamines were determined by differential fluorimetry [6].

\section{Results}

I. 24-h variations of blood sugar and plasma insulin levels in normal subjects receiving three different meals The variations of blood sugar and plasma insulin are outlined in Table 2.

The mean variations of blood sugar, plasma insulin and of the I/G ratio (plasma insulin/blood sugar) are illustrated in Fig. 1.

Blood sugar varied little during the night. During the three postprandial periods, the means of the peak values never exceeded $110 \mathrm{mg} / 100 \mathrm{ml}$, and were of the same order of magnitude.

Plasma insulin did not vary during the night. During the day, plasma insulin rose maximally after the morning and evening meals in group a, and only after the morning meal in group $b$.

The $I / G$ ratio dropped during the night, and increased after meals. In both groups this increase was maximal after the morning meal.

The plasma levels of non-esterified fatty acids measured in four of these subjects are shown in Fig. 2. These values were high $(600-1200 \mu \mathrm{Eq} / \mathrm{l})$ from $23 \mathrm{~h}$ to $1 \mathrm{~h}$, then fell progressively until $6 \mathrm{~h}$. They rose between the first and third hours after the beginning of the meals. The highest values $(800-1400 \mu \mathrm{Eq} / \mathrm{l})$ were observed between the second and fifth hours of the postprandial period.

Plasma cortisol values and urinary catecholamines levels are listed in Tables 3 and 4.

Plasma cortisol was lowest at $24 \mathrm{~h}$. It then rose to a maximum at $8 \mathrm{~h}$, and dropped progressively during the course of the day.

Adrenaline and noradrenaline excretion is statistically lower between $20 \mathrm{~h}$ and $8 \mathrm{~h}$ than between $8 \mathrm{~h}$ and $20 \mathrm{~h}$, but such a difference does not exist for urinary vanilmandelic acid.

\section{Diurnal variations in blood sugar and plasma insulin in normal subjects receiving three identical meals}

\section{A. Experimental data}

Variations in blood sugar and plasma insulin are given in Table 5 . 
The mean variations of blood sugar, plasma insulin and the $\mathrm{I} / \mathrm{G}$ ratio are shown in Fig. 3.

The mean peak value for blood was attained at the 45th min after each meal. It reached a higher level and decreased more rapidly after the morning meal than after either the midday or evening meals.

The mean plasma insulin level, as well, was higher

\section{Group a}
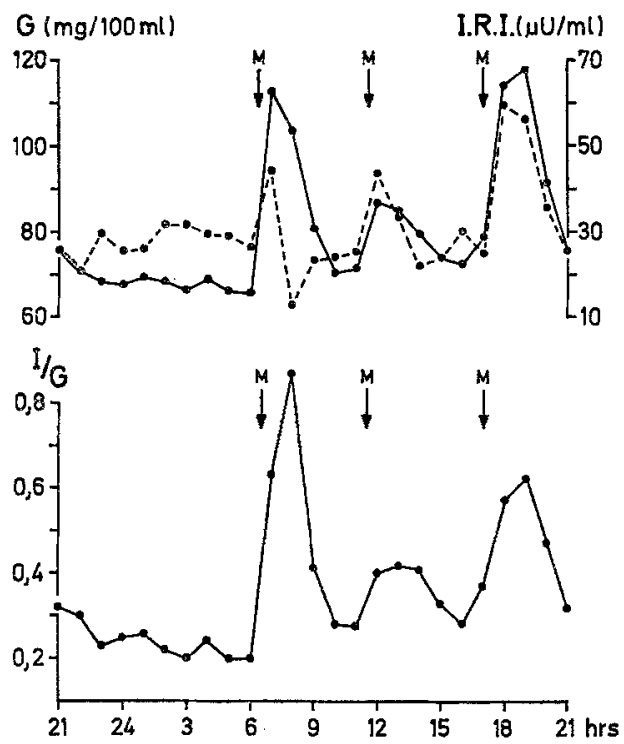

which was maximal in the morning, and lasted longer during the evening.

\section{B. Statistical analysis of the results}

The values of blood sugar, plasma insulin and the G/I ratio ${ }^{1}$, converted into logarithms, have been sub. mitted to an analysis of variance.

Fig. 1. Circadian variations of blood sugar (-.), plasma insulin (-) and the I/G ratio in seven normal subjects receiving three different meals $(M)$, at $6.30 \mathrm{~h}, 11.30 \mathrm{~h}$ and $17 \mathrm{~h}$ Group a: FRA.., MAT.., BRI.., DUN..

Group b: TOU.., DUC.., VAN.. (see Table 2)
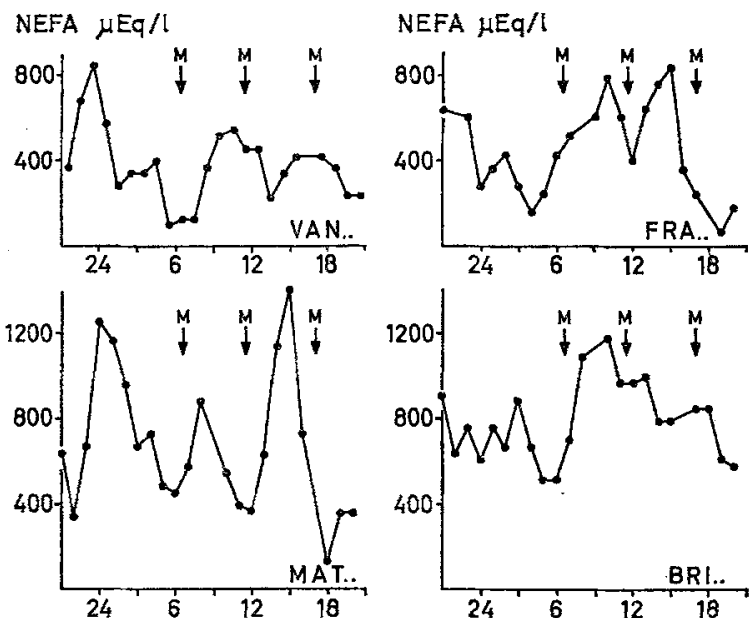

Fig. 2. NEFA levels in four normal subjects receiving three different meals (M), at $6.30 \mathrm{~h}, 11.30 \mathrm{~h}$ and $17 \mathrm{~h}$

after the morning meal than after either the midday or evening meals. In the evening, this level remained elevated until the 210 th min of the postprandial period, whereas in the morning and at noon it returned to a basal value between the 120 th and 150 th $\mathrm{min}$.

Each meal produced an elevation of the I/G ratio,

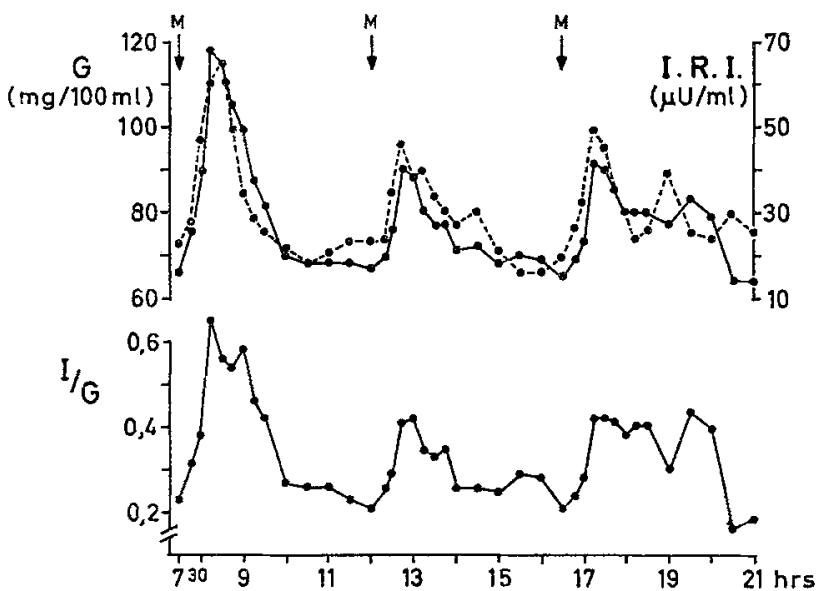

Fig. 3. Mean variations of blood sugar (...), plasma insulin $(-)$ and the $I / G$ ratio in five normal subjects receiving three identical meals (M), at $7.30 \mathrm{~h}, 12 \mathrm{~h}$ and $16.30 \mathrm{~h}$

The sources of variations were: time, period of day (morning, midday and evening) and the "time $x$ period of day" interaction.

1 The inverse ratio $G / I$ was utilized instead of the $I / G$ ratio to facilitate calculation. 
Table 2. Circadian variations of blood sugar (G) and plasma insulin (I,R.I.) in seven normal subjects receiving three different meals, at $6.30 \mathrm{~h}, 11.30 \mathrm{~h}$ and $17 \mathrm{~h}$

\begin{tabular}{|c|c|c|c|c|c|c|c|c|}
\hline \multirow{2}{*}{$\begin{array}{l}\text { Time } \\
\text { (hours) }\end{array}$} & \multicolumn{2}{|l|}{ Fra. } & \multicolumn{2}{|l|}{ Mat. } & \multicolumn{2}{|l|}{ Bri. } & \multicolumn{2}{|l|}{ Dun. } \\
\hline & $\begin{array}{l}\text { G } \\
(\mathrm{mg} \%)\end{array}$ & $\begin{array}{l}\text { T.R.I. } \\
(\mu \mathrm{U} / \mathrm{ml})\end{array}$ & $\begin{array}{l}\text { G } \\
(\mathrm{mg} \%)\end{array}$ & $\begin{array}{l}\text { I.R.I. } \\
(\mu \mathrm{U} / \mathrm{ml})\end{array}$ & $\begin{array}{l}\mathrm{G} \\
(\mathrm{mg} \%)\end{array}$ & $\begin{array}{l}\text { T.R.I. } \\
(\mu \mathrm{U} / \mathrm{ml})\end{array}$ & $\begin{array}{l}\mathrm{G} \\
(\mathrm{mg} \%)\end{array}$ & $\begin{array}{l}\text { I. R.I. } \\
(\mu \mathrm{U} / \mathrm{ml})\end{array}$ \\
\hline 21.00 & 79 & 5 & 71 & 26 & 83 & 44 & 72 & 26 \\
\hline 22.00 & 80 & 1 & 79 & 23 & 64 & 35 & $6 \overline{2}$ & 24 \\
\hline 23.00 & 82 & 2 & 76 & 23 & 92 & 31 & 69 & 17 \\
\hline 24.00 & 83 & 5 & 91 & 21 & 66 & 23 & 63 & 21 \\
\hline 1.00 & 72 & 3 & 98 & 26 & 66 & 27 & 68 & 23 \\
\hline 2.00 & 80 & 6 & 92 & 24 & 75 & 24 & 79 & 19 \\
\hline 3.00 & 74 & 4 & 96 & 20 & 78 & 19 & 78 & 22 \\
\hline 4.00 & $8 \overline{1}$ & 14 & 94 & 21 & 66 & 15 & 76 & 26 \\
\hline 5.00 & 73 & 7 & 94 & 20 & 75 & 12 & 74 & 25 \\
\hline 6.00 & 63 & 3 & 93 & 24 & 77 & 12 & $7 \overline{2}$ & 24 \\
\hline 7,00 & 84 & 19 & 107 & 113 & 88 & 35 & 98 & 82 \\
\hline 8.00 & 56 & 17 & 108 & 96 & 43 & 46 & 45 & 54 \\
\hline 9.00 & 66 & 8 & 99 & 51 & 66 & 34 & 63 & 30 \\
\hline 10.00 & 76 & 3 & 80 & 35 & 78 & 20 & 62 & 24 \\
\hline 11.00 & 76 & 5 & 88 & 39 & 74 & 22 & 63 & 19 \\
\hline 12.00 & 111 & 37 & 84 & 47 & 111 & 40 & 67 & 23 \\
\hline 13.00 & 80 & 22 & 92 & 39 & 80 & 36 & 80 & 43 \\
\hline 14.00 & 60 & 21 & 69 & 31 & 83 & 34 & 76 & 32 \\
\hline 15.00 & 66 & 13 & 79 & 30 & 78 & 27 & 72 & 29 \\
\hline 16.00 & 74 & 25 & 85 & 23 & 77 & 16 & 84 & 26 \\
\hline 17.00 & 74 & 17 & 81 & 51 & 81 & 20 & 64 & 25 \\
\hline 18.00 & 81 & 23 & 107 & 90 & 153 & 83 & 97 & 60 \\
\hline 19.00 & 82 & 18 & 106 & 96 & 128 & 66 & 108 & 91 \\
\hline \multirow[t]{27}{*}{20.00} & 73 & 13 & 92 & 60 & 86 & 36 & 92 & 57 \\
\hline & Time & Tou. & & Due. & & Van. & & \\
\hline & (hours) & $\begin{array}{l}\overline{\mathrm{G}} \\
(\mathrm{mg} \%)\end{array}$ & $\begin{array}{l}\text { T.R.I. } \\
(\mu \mathrm{U} / \mathrm{ml})\end{array}$ & $\begin{array}{l}\mathrm{G} \\
(\mathrm{mg} \%)\end{array}$ & $\begin{array}{l}\overline{\text { I.R.I. }} \\
(\mu \mathrm{U} / \mathrm{ml})\end{array}$ & $\begin{array}{l}\overline{\mathrm{G}} \\
(\mathrm{mg} \%)\end{array}$ & $\begin{array}{l}\text { I.R.I. } \\
(\mu \mathrm{U} / \mathrm{ml})\end{array}$ & \\
\hline & 21.30 & 69 & 23 & 68 & 47 & 73 & 20 & \\
\hline & 22.30 & 53 & 19 & 97 & 65 & 56 & 6 & \\
\hline & 23.30 & 63 & 17 & 60 & 12 & 72 & 15 & \\
\hline & 24.30 & 63 & 19 & 61 & 11 & 84 & 7 & \\
\hline & 1.30 & 65 & 17 & 66 & 11 & 79 & 3 & \\
\hline & 2.30 & 63 & 17 & 70 & 11 & 65 & 6 & \\
\hline & 3.30 & 60 & 17 & 74 & 11 & 71 & 3 & \\
\hline & 4.30 & 61 & 16 & 71 & 6 & 68 & 6 & \\
\hline & 5.30 & 53 & 16 & 80 & 3 & 66 & 3 & \\
\hline & 6.30 & 56 & 24 & 74 & 11 & 62 & 11 & \\
\hline & 7.30 & 88 & 51 & 84 & - & 116 & 79 & \\
\hline & 8.30 & 68 & 33 & 91 & 46 & 82 & 66 & \\
\hline & 9.30 & 77 & 31 & 86 & 41. & 67 & 28 & \\
\hline & 10.30 & 69 & 20 & 67 & 27 & 56 & 12 & \\
\hline & 11.30 & 67 & 18 & 67 & 13 & 67 & 10 & \\
\hline & 12.30 & 78 & 24 & 87 & 37 & 77 & 42 & \\
\hline & 13.30 & 79 & 31 & 84 & 32 & 89 & 80 & \\
\hline & 14.30 & 68 & 28 & 105 & 16 & 83 & 31 & \\
\hline & 15.30 & 58 & 26 & 73 & 19 & 62 & 23 & \\
\hline & 16.30 & 73 & 25 & 76 & 15 & 78 & 14 & \\
\hline & 17.30 & 63 & 32 & 78 & 30 & 79 & 17 & \\
\hline & 18.30 & 103 & 40 & 85 & 33 & 89 & 35 & \\
\hline & 19.30 & 104 & 40 & 95 & 57 & 95 & 34 & \\
\hline & 20.30 & 79 & 32 & 88 & 23 & 82 & 14 & \\
\hline
\end{tabular}

The results of this analysis of variance are presented in Table 6.

For the blood sugar values the time effect was significant, implying that the blood sugar changed throughout the day. However, the period of day and the "time $x$ period of day" interaction effects were not significant, implying that the mean blood glucose and the pattern of variation were not different during the three postprandial periods.
The plasma insulin also varied with time, but the mean concentration of insulin was different, and the modifications of the plasma insulin did not display the same pattern during the three postprandial periods.

In order to localize the period effect, orthogonal contrasts were employed. The chosen contrasts were:

$\mathrm{L}_{1}=2 \times$ morning values - (midday + evening values)

$\mathrm{L}_{2}=-$ midday values + evening values 
Table 3. Plasma cortisola (mean $\pm \sigma$ ) during a 24-h period in six normal subjects

\begin{tabular}{llllll}
\hline $24 \mathrm{~h}$ & $4 \mathrm{~h}$ & $8 \mathrm{~h}$ & $12 \mathrm{~h}$ & $17 \mathrm{~h}$ & $20 \mathrm{~h}$ \\
\hline $4.2 \pm 5.0$ & $10.7 \pm 3.9$ & $17.0 \pm 4.8$ & $15.5 \pm 3.6$ & $8.6 \pm 4.5$ & $8 \pm 4.7$ \\
\hline $\mathrm{a} \mu \mathrm{g} / 100 \mathrm{ml}$ & & &
\end{tabular}

Table 4. Urinary catecholamines (mean $\pm \sigma$ ) during a $24 \mathrm{~h}$ period in seven normal subjects

\begin{tabular}{llll}
\hline & Night & Day \\
\hline Adrenaline & $(\mu \mathrm{g} / 12 \mathrm{~h})$ & $2.60 \pm 1.5^{\mathrm{a}}$ & $\mathbf{5 . 5 8 \pm 2 . 7 4 ^ { \mathrm { a } }}$ \\
Noradrenaline $(\mu \mathrm{g} / 12 \mathrm{~h})$ & $8.87 \pm 3.68^{\mathrm{b}}$ & $\mathbf{3 1 . 1 5 \pm 1 2 . 2 0 ^ { \mathrm { b } }}$ \\
V.M.A. & $(\mu \mathrm{g} / 12 \mathrm{~h})$ & $\mathbf{5 . 3 0 \pm 1 . 3 0}$ & $6.82 \pm 2.4$ \\
\hline
\end{tabular}

$\left.\begin{array}{l}\text { a } p<0.05 \\ \text { b } p<0.001\end{array}\right\}$ Student's $t$ test
The " $F$ " values for these two contrasts, as well as their significance, are presented in Table 7 .

The insulin concentration in peripheral blood was greater in the morning postprandial period than in the other two, and it was higher in the evening than at midday.

The insulin response was, therefore, maximal in the morning, minimal at midday and intermediary in the evening.

The $G / I$ ratio varied throughout the day. Its variations were different in magnitude, but not in pattern, from one period to another.

Table 5. Variations of blood sugar (G) and plasma insulin (I.R.I.) in five normal subjects receiving three identical meals, at $7.30 \mathrm{~h}, 12 \mathrm{~h}$ and $16.30 \mathrm{~h}$

\begin{tabular}{|c|c|c|c|c|c|c|c|c|c|c|}
\hline \multirow{2}{*}{$\begin{array}{l}\text { Time } \\
\text { (hours) }\end{array}$} & \multicolumn{2}{|l|}{ Ron. } & \multicolumn{2}{|l|}{ Blo. } & \multicolumn{2}{|l|}{ War. } & \multicolumn{2}{|l|}{ Ver. } & \multicolumn{2}{|l|}{ Cau. } \\
\hline & $\begin{array}{l}\mathrm{G} \\
(\mathrm{mg} \%)\end{array}$ & $\begin{array}{l}\text { I.R.I. } \\
(\mu \mathrm{U} / \mathrm{ml})\end{array}$ & $\begin{array}{l}\mathrm{G} \\
(\mathrm{mg} \%)\end{array}$ & $\begin{array}{l}\text { I.R.I. } \\
(\mu \mathrm{U} / \mathrm{ml})\end{array}$ & $\begin{array}{l}\mathrm{G} \\
(\mathrm{mg} \%)\end{array}$ & $\begin{array}{l}\text { I.R.I. } \\
(\mu \mathrm{U} / \mathrm{ml})\end{array}$ & $\begin{array}{l}\mathrm{G} \\
(\mathrm{mg} \%)\end{array}$ & $\begin{array}{l}\text { I.R.I. } \\
(\mu \mathrm{U} / \mathrm{ml})\end{array}$ & $\begin{array}{l}\overline{\mathrm{G}} \\
(\mathrm{mg}\end{array}$ & $\begin{array}{l}\text { I.R.I. } \\
(\mu \mathrm{U} / \mathrm{ml})\end{array}$ \\
\hline 7.30 & 70 & 18 & 70 & 13 & 74 & 18 & 74 & 12 & 73 & 21 \\
\hline 7.50 & 71 & 17 & 83 & 23 & 81 & 25 & 66 & 15 & 89 & 48 \\
\hline 8.00 & 76 & 20 & 110 & 29 & 110 & 42 & 61 & 28 & 127 & 75 \\
\hline 8.15 & 101 & 45 & 138 & 50 & 113 & 60 & 78 & 96 & 122 & 85 \\
\hline 8.30 & 108 & 40 & 140 & 50 & 106 & 58 & 102 & 81 & 115 & 90 \\
\hline 8.45 & 91 & 34 & 126 & 41 & 84 & 34 & 89 & 38 & 106 & 130 \\
\hline 9.00 & 81 & 26 & 91 & 35 & 77 & 34 & 90 & 54 & 81 & 95 \\
\hline 9.15 & 75 & 26 & 89 & 20 & 67 & 24 & 77 & 31 & 81 & 83 \\
\hline 9.30 & 80 & 20 & 78 & 17 & 77 & 30 & 73 & 29 & 66 & 60 \\
\hline 10.00 & 85 & 16 & 64 & 14 & 66 & 23 & 70 & 14 & 71 & 31 \\
\hline 10.30 & 68 & 20 & 67 & 10 & 78 & 21 & 70 & 9 & 56 & 28 \\
\hline 11.00 & 71 & 20 & 73 & 14 & 70 & 29 & 64 & 10 & 70 & 22 \\
\hline 11.30 & 80 & 20 & 75 & 16 & 69 & 24 & 69 & 10 & 73 & 18 \\
\hline 12.00 & 83 & 18 & 75 & 13 & 69 & 24 & 63 & 10 & 74 & 14 \\
\hline 12.20 & 73 & 21 & 83 & 20 & 62 & 22 & 60 & 10 & 87 & 23 \\
\hline 12.30 & 80 & 25 & 110 & 28 & 67 & 30 & 62 & 8 & 102 & 37 \\
\hline 12.45 & 86 & 45 & 133 & 33 & 77 & 33 & 73 & 17 & 112 & 73 \\
\hline 13.00 & 76 & 50 & 126 & 41. & 79 & 33 & 72 & 10 & 89 & 55 \\
\hline 13.15 & 76 & 25 & 107 & 36 & 84 & 33 & 98 & 17 & 78 & 40 \\
\hline 13.30 & 80 & 34 & 98 & 24 & 84 & 29 & 75 & 21 & 76 & 29 \\
\hline 13.45 & 60 & 20 & 100 & 32 & 78 & 32 & 91 & 23 & 70 & 28 \\
\hline 14.00 & 68 & 19 & 95 & 30 & 80 & 24 & 71 & 10 & 70 & 23 \\
\hline 14.30 & 88 & 33 & 87 & 18 & 88 & 26 & 70 & 10 & 69 & 23 \\
\hline 15.00 & 70 & 16 & 83 & 25 & 78 & 20 & 56 & 10 & 64 & 21 \\
\hline 15.30 & 71 & 20 & 77 & 23 & 70 & 29 & 59 & 14 & 53 & 15 \\
\hline 16.00 & 72 & 23 & 76 & 15 & 74 & 33 & 44 & 12 & 64 & 13 \\
\hline 16.30 & 75 & 18 & 75 & 10 & 70 & 23 & 63 & 8 & 61 & 16 \\
\hline 16.50 & 75 & 20 & 80 & 18 & 77 & 28 & 75 & 10 & 75 & 21 \\
\hline 17.00 & 75 & 21 & 94 & 21 & 74 & 34 & 80 & 10 & 87 & 31 \\
\hline 17.15 & 89 & 50 & 122 & 42 & 91 & 55 & 98 & 25 & 93 & 36 \\
\hline 17.30 & 80 & 43 & 131 & 39 & 100 & 53 & 69 & 25 & 96 & 42 \\
\hline 17.45 & 70 & 30 & 119 & 36 & 70 & 47 & 70 & 15 & 97 & 45 \\
\hline 18.00 & 65 & 33 & 101 & 29 & 54 & 23 & 79 & 17 & 99 & 50 \\
\hline 18.15 & 79 & 26 & 81 & 26 & 49 & 24 & 70 & 20 & 90 & 55 \\
\hline 18.30 & 62 & 25 & 94 & 25 & 63 & 24 & 79 & 18 & 80 & 60 \\
\hline 19.00 & 70 & 16 & 92 & 28 & 68 & 31 & 77 & 26 & 137 & 34 \\
\hline 19.30 & 80 & 47 & 97 & 25 & 60 & 23 & 71 & 42 & 68 & 26 \\
\hline 20.00 & 64 & 18 & 87 & 24 & 79 & 37 & 70 & 48 & 71 & 20 \\
\hline 20.30 & 75 & 13 & 78 & 16 & 72 & 14 & 79 & 10 & 94 & 15 \\
\hline 21.00 & 71 & 14 & 71 & 14 & 82 & 13 & 77 & 13 & 75 & 15 \\
\hline
\end{tabular}


The contrasts used to localize the "period of day" effect were the same as those chosen for the insulin levels.

The " $F$ " value for these contrasts, and their significance, are given in Table 7 .

The variations in the G/I ratio were statistically different when one compared the morning with the sum of the midday and the evening, and the midday with the evening only.

Thus the $I / G$ ratio was, like insulin, maximal in the morning, minimal at midday and intermediary in the evening.
The derived function $\frac{d i}{d t}$ may be determined by the linear distribution of these discontinuous values, for example:

$$
\left(\frac{d i}{d t}\right)=\frac{i_{j+1}-i_{j-1}}{2 \Delta t}
$$

or $\left(\frac{d i}{d t}\right)=\frac{i_{j}-i_{j-1}}{\Delta t}$ if the determinations are very close

where $\Delta t$ is the time interval between two determinations.

Table 6. Analysis of variance (" $F$ " values) for blood sugar (G), plasma in. sulin $(I)$ and the $G / I$ ratio in five normal subjects receiving three identical meals during the day

\begin{tabular}{|c|c|c|c|c|}
\hline \multirow[b]{2}{*}{ Sources of variation } & \multirow{2}{*}{$\begin{array}{l}\text { Degree of } \\
\text { freedom }\end{array}$} & \multicolumn{3}{|c|}{ "F" values } \\
\hline & & $\bar{G}$ & $\mathrm{I}$ & $G / I$ \\
\hline Time & 12 & $7.39^{\mathrm{b}}$ & $16.08^{b}$ & $8.47^{\mathrm{a}}$ \\
\hline Period of day & 2 & 2.08 & $7.63^{b}$ & $4.51^{\mathrm{a}}$ \\
\hline "Time x period" & 24 & 1.15 & $2.02^{b}$ & 1.53 \\
\hline
\end{tabular}

a $p<0.05$

b $p<0.01$

Table 7. Analysis of variance (" $F$ " values) of the orthogonal contrasts for plasma insulin $(I)$ and the G/I ratio in five normal subjects receiving three identical meals during the day

\begin{tabular}{lll}
\hline Contrasts & 'F" values & \\
\cline { 2 - 3 } & $\mathrm{T}$ & $\mathrm{G} / \mathrm{I}$ \\
\hline $\mathrm{L}_{1} \mathrm{c}$ & $12.27^{\mathrm{b}}$ & $5.10^{\mathrm{a}}$ \\
$\mathrm{L}_{2} \mathrm{c}$ & $4.3^{\mathrm{a}}$ & $3.93^{\mathrm{a}}$ \\
\hline
\end{tabular}

a $p<0.05$

b $p<0.01$

c for definition of $L_{1}$ and $L_{2}$ see text.

C. Relationship between blood sugar and plasma insulin

The variations of plasma insulin occurred in a different pattern from one postprandial period to another, contrary to the variations of blood sugar. The relation existing between the postprandial modifications of plasma insulin and of the blood sugar was then studied. The equation proposed by Cerasi [2] to represent insulin production by the pancreas during prolonged glucose infusion was utilized for this purpose. The equation is as follows:

$\frac{d}{d t} i=k_{i} \cdot g \frac{1}{\tau_{i}}-i \frac{1}{\tau_{i}}$

where $i$ corresponds to the increase in plasma insulin above basal value in $\mu \mathrm{U} / \mathrm{ml}$

$g$ is the increase in blood sugar glucose concentration above basal value in $\mathrm{mg} / 100 \mathrm{ml}$ and $\tau_{i}$ the half-life of insulin set at $7 \mathrm{~min}$.

Our experimental curves give $i(t)$ and $g(t)$ in a discontinuous form:

$i_{0}, i_{1} \ldots i_{j} \ldots i_{n}$ and $g_{0}, g_{1} \ldots g_{j} \ldots g_{n}$.
The equation (1) gives:

$$
\begin{aligned}
g & =\frac{1}{k_{i}} i+\frac{\tau}{k_{i}} \frac{d i}{d t} \\
\text { or } g_{j} & =\frac{1}{k_{i}} i_{j}+\frac{\tau}{k_{i}}\left(\frac{i_{j}-i_{j-1}}{\Delta t}\right) \\
& =\alpha i_{j}+\beta i_{j-1}
\end{aligned}
$$

where $\alpha=\frac{1}{k_{i}}+\frac{\tau}{k_{i} \Delta t}$ and $\beta=-\frac{\tau}{k_{i} \Delta t}$.

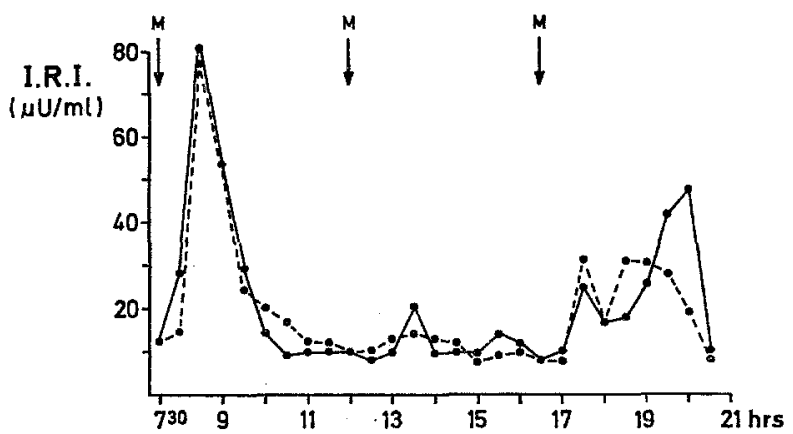

Fig. 4. Insulin variations in a normal subject (VER..) receiving three identical meals (M), at $7.30 \mathrm{~h}, 12 \mathrm{~h}$, and - experimental values $16.30 \mathrm{~h}$

... values calculated from the blood sugar curve

In the presence of values $g_{j}$ and $i_{j}$, an adjustment of $\alpha$ and $\beta$ may be obtained by the method of least squares. A program, written in "Fortran" language for the I. B. M. 360 computer, was used for this purpose. The 
three meals were considered independently, and preprandial values were used as basal levels.

Plasma insulin was first calculated from blood sugar levels, then blood sugar from plasma insulin levels.

Fig. 4 is representative of the results of this analysis in the five subjects studied.

The adjusted values corresponded to experimental data in all subjects after the morning meal. This was true not only when the blood sugar was calculated using the values of plasma insulin, but also when the plasma insulin was calculated using the blood sugar values. This suggests either a parallel variation of the two parame. ters independently of one another following the meal, or more likely, a very tight mutual influence, so that they cannot be dissociated.

The adjustments in either direction did not allow a satisfactory fit between the two parameters after the midday or the evening meals.

\section{Discussion}

In our study, blood sugar and plasma insulin were determined hourly for $24 \mathrm{~h}$ in seven normal male subjects. During the night, values were low: the blood sugar varied between 70 and $90 \mathrm{mg} / 100 \mathrm{ml}$, and plasma insulin oscillated slightly around a basal level of 15 $\mu \mathrm{U} / \mathrm{ml}$.

These results are comparable with those obtained in normal patients fasting from one night to three days $[18,8,23]$. Nevertheless, an elevation of plasma insulin at $24 \mathrm{~h}$ and $4 \mathrm{~h}$ was reported in patients suffering from various endocrinopathies, and in three normal subjects whose diet was unrestricted and who were not limited to the supine position [12]. The heterogeneity of this group of subjects and the inadequate control of their activities may be in part responsible for the discrepancy between this observation and our results.

During the day, the blood sugar variations were not statistically different when the same meal was given in the morning, at midday and in the evening.

In contrast, the insulin response did change according to the period of the day. In the morning, the increase in plasma insulin was early and important $(70 \mu \mathrm{U} / \mathrm{ml})$. At noon, the plasma insulin rise was minimal. In the evening, insulin levels were moderately high $(40 \mu \mathrm{U} /$ $\mathrm{ml})$, but remained elevated for a longer time. In addition, blood sugar and plasma insulin were closely related in the morning; this relation was partly lost at midday and in the evening.

The higher liberation of insulin observed after the morning meal, and which is expressed by a greater increase of the $I / G$ ratio at this time, could be explained by a resistance to the action of the hormone. Among the factors capable of bringing about a resistance to insulin, one may cite an increase in free fatty acids [19], catecholamines or plasma cortisol. Free fatty acids are not likely to be responsible, since their level is low at $6 \mathrm{~h}$ and it does not rise until plasma insulin has almost returned to normal. Adrenaline and noradrenaline will not induce a peripheral resistance either, as they are low during the morning hours; their inhibitory effect on the insulinogenic stimulus of the meals during the day is not apparent from our studies. However, plasma cortisol could be involved in a insulin resistance, since its values are most elevated in the morning.

The existence of an increased resistance to the action of insulin in the morning remains, nevertheless, subject to controversy. Thus, Specchia et al. [22] have not observed any modification of the peripheral assimilation of glucose during intravenous tolerance tests performed at different times during the day. Abrams et al. [1] have even found an increase of the blood sugar disappearance rate in the morning.

An elevation of the $I / G$ ratio in the morning has already been reported by Freinkel et al. [9] in eleven normal subjects fasting for three days. These authors have correlated this finding with the possible existence of a periodicity which would regulate insulin secretion independently of exogenous stimuli to insulin release.

Faiman and Moorhouse have previously proposed this hypothesis to explain the appearance of hyperglycaemic peaks at $8 \mathrm{~h}$ in the fasting diabetic, and the absence of this phenomenon in the normal subject. In the latter, indeed, a spontaneous insulin secretion would occur in the morning and prevent hyperglycaemia. This insulin would, however, not appear in the peripheral blood, because it would be trapped in the liver [8].

The modifications of plasma insulin response to meals from one period of the day to another could also be explained by the persistence of the activity of insulin liberated during the foregoing postprandial period, or by variations of pancreatic insulin reserves.

In fact, plasma insulin represents only a part of the insulin present in the various compartments of the body. Insulin liberated in the bloodstream diffuses rapidly towards interstitial fluids $[20,21]$, where its half-life is longer than in the blood [21]. It is thus possible that the activity of insulin is prolonged beyond the moment when plasma insulin returns to a basal value.

Hence, plasma insulin secreted during the first postprandial period could be fixed to the peripheral tissues and enhance the glucose assimilation at noon. Blood sugar homeostasis would thus be assured in the presence of a lower insulin response as observed after the midday meal. In the evening, this mechanism would only play a secondary role since the quantity of insulin liberated at noon is relatively small. Blood sugar equilibrium would then require a greater insulin secretion. The pancreas, however, does not seem to respond as rapidly to the ingestion of a meal in the evening as in the morning, as shown by the plasma insulin rise which is moderate and prolonged. This extended rise in plasma insulin suggests the occurrence of a new synthesis made necessary by a reduction of pancreatic insulin reserves. Indeed, as Howell and Taylor [11] have described, it takes about one hour for new insulin to be synthesized by the islet cell. 
The data of the present work may be compatible with a hypothesis of insulin dynamics which would reconcile variations in insulin release and synthesis with peripheral activity of the hormone. In this hypothesis, insulin storage could occur during the night. Pancreatic reserves would therefore be maximal in the morning, and allow a rapid output of hormone in response to the first meal. Insulin activity would persist for some time at the tissue level, so that the blood sugar homeostasis would eventually be facilited later on. Close correlation between blood sugar and plasma insulin will then be lost. By further repetition of the trigger, pancreatic reserves would eventually become limited, and new synthesis would be required.

Consequently, although insulin response would indeed depend on the caloric content of the meals as previously reported [4], it would also depend upon the period of the day when the meals are consumed and on their frequency.

This concept bears more weight in the light of the recent report on the relations between frequency of meals and incidence of ischaemic heart-disease; this latter occurring more frequently in subjects eating three times a day than in the ones having five meals a day [7].

Implications of alimentary habits upon pathological states in relation to insulin release or activity may not be only conjectural.

Acknowledgements. Mr. G. Gérard, Maître de Conférences aux Facultés Notre-Dame de la Paix, Namur, and Mr. R. Lorie, I.B.M. Center, Brussels, are gratefully acknowledged for their active collaboration on the statistical and mathematical aspects of this study. The skilled technical assistance of Mrs. B. De Bie and Mr. M. Decoster is also gratefully acknowledged.

Determinations of NEFA were kindly performed through the courtesy of Drs. P. Lefebvre and A. Luyckx (Liège University).

This work was supported by grants from the Fonds de la Recherche Scientifique Médicale, the Fondation Médicale Reine Elisabeth and the Eli Lilly and Co, Indianapolis, U.S.A.

\section{References}

1. Abrams, R.L., Cerchio, G.M., Graber, A. L.: Circadian variations of intravenous glucose tolerance in man. Diabetes 17, suppl. 1, 314 (1968).

2. Cerasi, E.: An analogue computer model for the insulin response to glucose infusion. Acta endocr. 55, $163-183$ (1967).

3. Cession-Fossion, A., Vandermeulen, R., Lefebvre, P., Legros, J.J.: Variations nycthémérales de la catécholaminémie chez l'homme normal au repos. Rev. med. Liège 22, 285-286 (1967).

4. Cohn, C., Berger, S., Norton, M.: Relationship between meal size and frequency and plasma insulin response in man. Diabetes 17, $72-75$ (1968).

5. Dole, V.P., Meinertz, H.: Microdetermination of long chain fatty acids in plasma and tissues. J. biol. Chem. 235, 2595-2599 (1960).

6. von Euler, U.S., Lishajko, F.: The estimation of catecholamines in urine. Acta physiol. scand. 45, $122-132$ (1959).

7. Fábry, P., Fodor, J., Hejl, Z., Geizerová, H., Balcarová, O.: Meal frequency and ischaemic heart-disease. Lancet 1968 II, 190-191.
8. Faiman, C., Moorhouse, J.A.: Diurnal variation in the levels of glucose and related substances in healthy and diabetic subjects during starvation. Clin. Sci. 32, $111-126$ (1967).

9. Freinkel, N., Mager, M., Vinnick, L.: Cyclicity in the interrelationships between plasma insulin and glucose during starvation in normal young men. J. Lab. clin. Med. 71, 171-178 (1968).

10. Hoffman, W.S.: Rapid photoelectric method for the determination of glucose in blood and urine. J. biol. Chem. 120, 51 - 55 (1937).

11. Howell, S.L., Taylor, K.W.: The secretion of newly synthesized insulin in vitro. Biochem. J. 102, 922-927 (1967).

12. Lambert, A.E., Hoet, J.J.: Diurnal pattern of plasma insulin concentration in the human. Diabetologia 2 , $69-72(1965)$

13. Migeon, C.J., Tyler, F.H., Mahoney, J.P., Florentin, A.A., Castle, H., Bliss, E.L., Samuels, L.T.: 'The diurnal variation of plasma levels and urinary excre. tion of 17-hydroxycorticosteroïds in normal subjects, night workers and blind subjects. J. clin. Endocr. 16, $622-633(1956)$.

14. Morgan, C.R., Lazarow, A.: Immunoassay of insulin: two antibody systems. Plasma insulin levels of normal, subdiabetic and diabetic rats. Diabetes 12, 115-126 (1963).

15. Pauly, J.E., Scheving, L.E.: Circadian rhythms in blood glucose and the effect of different lighting schedules, hypophysectomy, adrenal medullectomy and starvation. Amer. J. Anat. 120, 627--636 (1967).

16. Peterson, R. F., Karrer, A., Guerra, S.I.: Evaluation of Silber-Porter procedure for determination of plasma hydrocortisone. Analyt. Chem. 29, 144-149 (1957).

17. Pitts, G.C.: Diurnal rhythm in blood sugar of the white rat. Amer. J. Physiol. 139, 109-116 (1943).

18. Quabbe, H.J., Schilling, E., Helge, H.: Pattern of growth hormone secretion during a 24-hour fast in normal adults. J. clin. Endocr. 26, $1173-1177$ (1966).

19. Randle, P.J., Garland, P.B., Hales, C.N., Newsholme, E.A.: The glucose fatty-acid cycle. Its role in insulin sensitivity and the metabolic disturbances of diabetes mellitus. Lancet $1963 \mathrm{I}, 785-789$.

20. Rasio, E.A., Hampers, C.L., Soeldner, J.S., Cahill, G.F.: Diffusion of glucose, insulin, inulin, and Evans blue protein into thoracic duct lymph of man. J. clin. Invest. 46, 903-910 (1967).

21. - Hill, G.J., Soeldner, J.S., Herrera, M.G.: Effect of pancreatectomy on glucose tolerance and extracellular fluid insulin in the dog. Diabetes 16, 551-556 (1967).

22. Specchia, G., Tavazzi, L., Fratino, P., Petroboni, V.: Variazioni dell'assimilazione glucidica durante la giornata. I) Variazioni nel soggetto normale e nel soggetto con obesità essenziale. Boll. Soc. ital. Biol. sper. 43, 1891-1894 (1967).

23. Takahashi, Y., Kipnis, D.M., Daughaday, W.H.: Growth hormone secretion during sleep.J. clin. Invest. 47, 2079-2090 (1968).

24. Zarrow, M.X., Denison, M.E., Rosenberg, B., Mann, D.E., Jr., Neher, G.M.: Effect of insulin and epinephrine on the eosinophil and blood glucose levels in sheep; lack of diurnal rhythm. Amer. J. Physiol. $171,636-640$ (1952).

Dr. Christian Malherbe

Dr. Joseph J. Hoet

Laboratoire de Recherches de la

Clinique Médicale

Hôpital Saint-Pierre

69 , Brusselsestraat

Louvain, Belgique. 